\title{
Identification of glacier motion and potentially dangerous glacial lakes in the Mt. Everest region/Nepal using spaceborne imagery
}

\author{
T. Bolch ${ }^{1,4}$, M. F. Buchroithner ${ }^{1}$, J. Peters ${ }^{1}$, M. Baessler ${ }^{2}$, and S. Bajracharya ${ }^{3}$ \\ ${ }^{1}$ Institut für Kartographie, Technische Universität Dresden, Germany \\ ${ }^{2}$ Institut für Planetare Geodäsie, Technische Universität Dresden, Germany \\ ${ }^{3}$ International Centre for Integrated Mountain Development (ICIMOD), Nepal \\ ${ }^{4}$ Geography Program, University of Northern British Columbia, BC, Canada
}

Received: 17 July 2008 - Revised: 8 October 2008 - Accepted: 16 October 2008 - Published: 4 December 2008

\begin{abstract}
Failures of glacial lake dams can cause outburst floods and represents a serious hazard. The potential danger of outburst floods depends on various factors like the lake's area and volume, glacier change, morphometry of the glacier and its surrounding moraines and valley, and glacier velocity. Remote sensing offers an efficient tool for displacement calculations and risk assessment of the identification of potentially dangerous glacial lakes (PDGLs) and is especially helpful for remote mountainous areas. Not all important parameters can, however, be obtained using spaceborne imagery. Additional interpretation by an expert is required. ASTER data has a suitable accuracy to calculate surface velocity. Ikonos data offers more detail but requires more effort for rectification. All investigated debris-covered glacier tongues show areas with no or very slow movement rates. From 1962 to 2003 the number and area of glacial lakes increased, dominated by the occurrence and almost linear areal expansion of the moraine-dammed lakes, like the Imja Lake. Although the Imja Lake will probably still grow in the near future, the risk of an outburst flood (GLOF) is considered not higher than for other glacial lakes in the area. Potentially dangerous lakes and areas of lake development are identified. There is a high probability of further lake development at Khumbu Glacier, but a low one at Lhotse Glacier.
\end{abstract}

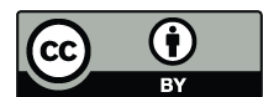

Correspondence to: $\mathrm{T}$. Bolch

(tobias.bolch@tu-dresden.de)

\section{Introduction}

Climate change and concomitant glacier recession can lead to the development and expansion of glacial lakes in mountain areas of the world. Failures of the lake dams can cause outburst floods and represent serious hazards. This is especially true for populated regions. Since the beginning of last century the number of glacial lake outburst floods (GLOFs) increased in the Himalaya (Richardson and Reynolds, 2000). Previous studies showed already that the risk of lake development is highest where the glaciers have a low slope angle and a low flow velocity or are stagnant (Quincey et al., 2007; Reynolds 2000). Whether glacial lakes become dangerous depends largely on their elevation relative to the spillway over the surrounding moraine (Benn et al., 2001; Sakai et al., 2007). Triggering events for an outburst can be moraine failures induced by an earthquake, by the decrease of permafrost and increased water pressure, or a rock or snow avalanche slumping into the lake causing an overflow (Buchroithner et al., 1982; Ives, 1985; Viuchard and Zimmerman, 1987). The glacier type is also of importance. Debris-covered glaciers respond to a negative mass balance by thinning, while their terminus position can remain relatively stable. Supraglacial lakes may be formed by supraglacial melting on low slope glaciers. Many of those lakes are ephemeral and drain when they connect the englacial drainage system ("perched lakes", Benn et al., 2001; Gulley and Benn, 2007). The meltwater discharging from steeper glacier portions can collect behind the terminal moraine and form "base level lakes" which drain when a spillway is incised into the moraine or when the moraine dam fails (Benn et al., 2001). 


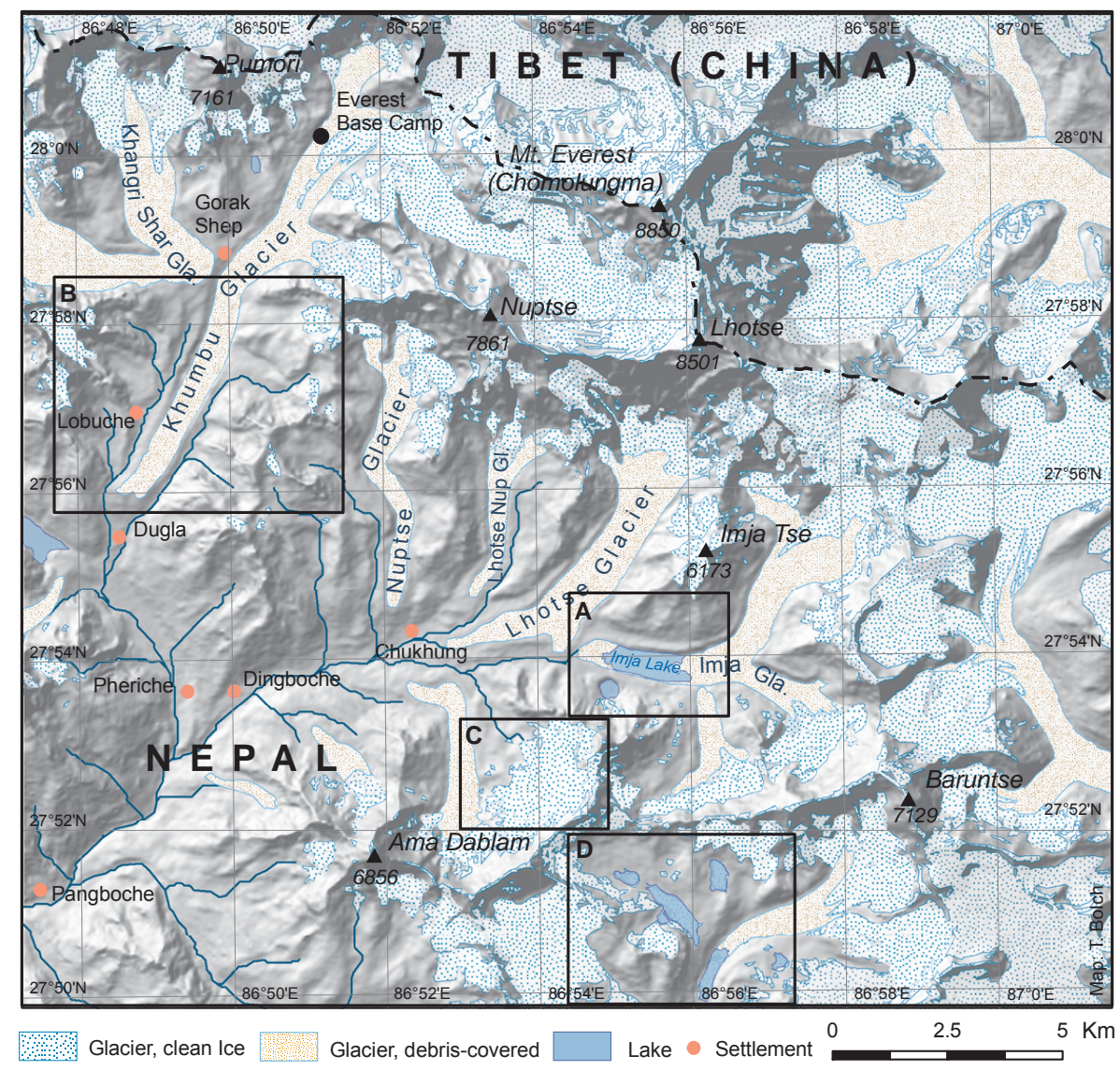

Fig. 1. Map of the study area based on ASTER data from November 2003. The marked areas are shown in detail in Fig. 2.

Multi-temporal and stereo remote sensing data are ideal to study the development of relief and lakes as well as glacier dynamics (Berthier et al., 2005; Bolch et al., 2007; Fujita et al., 2008; Huggel et al., 2002; Kääb, 2005; Kääb et al., 2005; Quincey et al., 2005). In addition, remote sensing is the best way to investigate a larger number of glaciers, glacial lakes and the impact of GLOFs in remote mountainous areas simultaneously, although relief-inducted factors hamper the use of remote sensing data (Buchroithner, 1995). Remote sensing-based measurements of glacier dynamics can provide area-wide information of glacier activity for entire glacier tongues instead of pointwise measurements. This is especially important for the detection of stagnant glacier parts in debris-covered glaciers. Moreover, glacier dynamics can also shed light on climate change in remote mountain areas where often no climate stations exist (Kääb, 2005). Measurements of the glacier velocity based on remote sensing data were published for Khumbu, Lhotse and Imja Glacier (Luckman et al., 2007; Quincey et al., 2007; Scherler et al., 2008; Nakawo et al., 1999).
In order to asses the potential danger of the glacial lakes, the reasons for their formation, their development, and the characteristics of their surroundings must be investigated. Several main factors influence the development and the potential danger of a glacial lake (Table 1). Most of them can be well addressed using multi-temporal spaceborne stereoimagery. It is also important to take into account the situation down-valley (e.g. the potential path of the flood and the affected population and infrastructure).

The aim of the present study is to show the suitability of multi-temporal optical remote sensing data to identify potential dangerous glacial lakes (PDGLs) and to illustrate the main causes of the lake development. In addition PDGLs in the Mt. Everest Region are named and possible sites for the development of PDGLs are identified. Moreover, the accuracy of multi-temporal ASTER and Ikonos data is addressed.

\section{Study area}

The glacier motion patterns and the development of PDGLs sare studied in the Mt. Everest Region south of the world's highest peak (in Tibetan: Qomolangma, $8850 \mathrm{~m}$., Fig. 1). 
Table 1. Key factors contributing to the hazard risk of a glacial lake and its investigation using remote sensing data (based on Huggel et al., 2002; Quincey et al., 2005; Richardson and Reynolds, 2000).

\begin{tabular}{|c|c|c|}
\hline Factor & Remote sensing data source and applicable techniques & $\begin{array}{l}\text { References with respect to Khumbu } \\
\text { Himalaya }\end{array}$ \\
\hline $\begin{array}{l}\text { 1. Lake volume, rate of lake forma- } \\
\text { tion and growth }\end{array}$ & $\begin{array}{l}\text { Change detection using multi-temporal (MT) and multi- } \\
\text { spectral (MS) satellite data }\end{array}$ & $\begin{array}{l}\text { Wessels et al., 2002; Bajracharya et } \\
\text { al., } 2007\end{array}$ \\
\hline $\begin{array}{l}\text { 2. Reaction of the glacier to climate } \\
\text { change }\end{array}$ & $\begin{array}{l}\text { Investigation of area and volume change of the glacier } \\
\text { based on MS and MT satellite data, MT digital terrain } \\
\text { models (DTMs) }\end{array}$ & Bolch et al., 2008 \\
\hline 3. Activity of the glacier & $\begin{array}{l}\text { Derive glacier velocity using feature tracking methods } \\
\text { based on MT optical or radar data }\end{array}$ & $\begin{array}{l}\text { Nakawo et al., 1999; Luckman et } \\
\text { al., 2007; Scherler et al., } 2008\end{array}$ \\
\hline $\begin{array}{l}\text { 4. Morphometric characteristics of } \\
\text { the glacier }\end{array}$ & Geomorphometric DTM analysis, slope classification & Bolch et al., 2007 \\
\hline $\begin{array}{l}\text { 5. Possibility of mass movements } \\
\text { into the lakes }\end{array}$ & $\begin{array}{l}\text { Mapping of ice cover and geology using MS data, Geo- } \\
\text { morphometric DTM analysis of the surrounding catch- } \\
\text { ment areas }\end{array}$ & \\
\hline $\begin{array}{l}\text { 6. Stability, width and height of the } \\
\text { moraine dam }\end{array}$ & Geomorphometric DTM analysis & $\begin{array}{l}\text { Buchroithner et al., 1982; Fujita et } \\
\text { al., } 2008\end{array}$ \\
\hline $\begin{array}{l}\text { 7. Freeboard between lake and crest } \\
\text { of moraine ridge }\end{array}$ & Geomorphometric DTM analysis & \\
\hline $\begin{array}{l}\text { 8. Presence of dead ice in the } \\
\text { moraine }\end{array}$ & $\begin{array}{l}\text { Investigation of surface deformation based on MT DTM } \\
\text { analysis }\end{array}$ & \\
\hline 9. Situation down-valley & $\begin{array}{l}\text { Geomorphometric DTM analysis, detection of human } \\
\text { infrastructure based on MS satellite data analysis. }\end{array}$ & Bajracharya et al. 2007 \\
\hline
\end{tabular}

The climate is influenced by the Indian monsoon, and 70$80 \%$ of the precipitation falls during the summer months (Ueno et al., 2001). The topography is characterised by huge relief differences and steep slopes. The upper valleys down to below $5000 \mathrm{~m}$ are filled by large debris-covered glacier tongues. The most recognisable change in these glaciers is due to downwasting (Bolch et al., 2008; Kadota et al., 2000). The end of the active debris-covered glacier tongue is not clearly identifiable, and it is likely that the investigated tongues contain parts of stagnant ice at the front which are connected with the active glacier-ice. Measurements of the glacier dynamics can clarify if these supposedly stagnant ice areas are expanding or not. At the Khumbu Glacier, the end of the active glacier tongue is estimated to be some $3 \mathrm{~km}$ upstream from the terminus (Fushimi, 1977; Luckman et al., 2007). Supraglacial ponds, ice-cliffs, and other thermo-karst features are typical for debris-covered tongues with their rough hummocky surface.

The study area is, like many in the Himalaya, a region where outburst floods occur. Receding glaciers supported the formation of large and rapidly growing glacial lakes in these mountain ranges, some of them being potentially dangerous (Richardson and Reynolds, 2000; Benn et al., 2000; Benn et al., 2001; Mool et al., 2001; Watanabe et al., 1994; Yamada, 1998). Within the last decades several outburst floods occurred and affected human lives and infrastructure. One of the most catastrophic events was the 1985 outburst of the Dig
Tsho in Mt. Everest Region which was triggered by an ice avalanche (Vuichard and Zimmermann, 1987). Some years earlier, in 1977, a GLOF caused by moraine dam failure originated from an adjacent valley (Nare Dranka, Buchroithner et al., 1982). A more recent GLOF occurred in September 1998 when the Sabai Tsho partly drained (Kattelmann, 2003).

\section{Data and methods}

\subsection{Data}

Multi-temporal space imagery from different sensors with different resolutions was used in order to assess the evolution of the glacial lakes within different time periods. Additional information from the mid 1980s was obtained from a topographic map (Table 2).

An ASTER DTM was generated in order to obtain information about the characteristics of the glaciers and their surroundings (e.g. slope gradients). The DTM with a resolution of $30 \mathrm{~m}$ based on scenes from 2001, 2002 and 2003 was generated using the PCI Geomatica 9.1 software. The ground control points (GCPs) are based on GPS measurements taken during the field work in spring 2006 and a topographic map (1:50 000, National Geographic Society 1988). The raw DTM contained several data gaps, mainly located at steep slopes, in shadowed and in snow-covered areas. The valleys, however, including the debris-covered glacier 
Table 2. Utilized remote sensing data and topographic map and its accuracy.

\begin{tabular}{|c|c|c|c|c|c|}
\hline Date & Source/Sensor & $\begin{array}{l}\text { Resolution/ } \\
\text { Scale }\end{array}$ & $\begin{array}{l}\text { Accuracy } \\
(\operatorname{RMSE} x, y)\end{array}$ & Application & Remarks with respect to lakes \\
\hline $1962 / 12 / 15$ & Corona KH-4 & $8 \mathrm{~m}$ & $\sim 15 \mathrm{~m}$ & Lake identification & Manual delineation \\
\hline $1975 / 10 / 15$ & Landsat MSS & $79 \mathrm{~m}$ & $\sim 50 \mathrm{~m}$ & Lake identification & $\begin{array}{l}\text { Automated delineation, some } \\
\text { ice on lakes }\end{array}$ \\
\hline 1984 & $\begin{array}{l}\text { Topographic map } \\
\text { (Nat. Geographic) }\end{array}$ & $1: 50000$ & Reference & Lake identification & Manual delineation \\
\hline $1992 / 17 / 11$ & Landsat TM & 30 & $\sim 30 \mathrm{~m}$ & Lake identification & $\begin{array}{l}\text { Automated delineation, some } \\
\text { ice on lakes }\end{array}$ \\
\hline $2000 / 10 / 30$ & Landsat ETM+ & $30 \mathrm{~m} / 15 \mathrm{~m}$ & $\sim 30 \mathrm{~m}$ & Lake identification & Automated delineation \\
\hline 2000/12/18 & Ikonos & $2 \mathrm{~m}$ & $\sim 5.6 \mathrm{~m}$ & $\begin{array}{l}\text { Lake identification, } \\
\text { glacier velocity }\end{array}$ & Manual delineation \\
\hline $2001 / 11 / 29$ & Ikonos & $2 \mathrm{~m}$ & $\sim 7.1 \mathrm{~m}$ & Glacier velocity & \\
\hline $2001 / 12 / 20$ & Terra ASTER & $15 \mathrm{~m}$ & $\sim 12 \mathrm{~m}$ & Glacier velocity & \\
\hline $2003 / 23 / 11$ & Terra ASTER & $15 \mathrm{~m}$ & $\sim 12 \mathrm{~m}$ & $\begin{array}{l}\text { Lake identification, } \\
\text { glacier velocity }\end{array}$ & Automated delineation \\
\hline $2005 / 29 / 11$ & Terra ASTER & $15 \mathrm{~m}$ & $\sim 15 \mathrm{~m}$ & Lake identification & $\begin{array}{l}\text { Automated delineation, some } \\
\text { ice on lakes }\end{array}$ \\
\hline
\end{tabular}

tongues, are well represented. In postprocessing steps, data gaps were filled with terrain information derived from the National Geographic Society map (Buchroithner and Bolch, 2007). An accuracy assessment based on 205 individual control points taken from the National Geographic map and distributed over non-glaciated area shows that $\mathrm{rms}_{z}$ error is less than 30 metre. Hence, the accuracy is acceptable given the very steep slopes and the high relief differences of up to $5000^{\circ} \mathrm{m}$. In addition, the $\mathrm{rms}_{z}$ error is significantly smaller $(<15 \mathrm{~m})$ within a buffer of $500 \mathrm{~m}$ around the glacier tongues (Bolch et al., 2008). The ASTER DTM was also used for ortho-rectification of the satellite imagery. The $\mathrm{rms}_{x, y}$ errors for the different data (Table 2) are sufficient, taking into account the extreme relief.

The calculation of the glacier velocity is based on ASTER data from 2001 and 2003 as well as Ikonos data from 2000 and 2001. The high-resolution multi-temporal Ikonos data cover a large part of the debris-covered tongue of the Khumbu Glacier and about half of the Nuptse Glacier, while ASTER data cover the whole investigation area. Unfortunately, the Ikonos data were only available divided into three segments, each of them with its own rational polynomial coefficient (RPC) including the camera model. Thus, each segment had to be ortho-rectified separately. Since the overlap only amounted to 100 pixels, this led to inaccuracies, and it was not possible to find enough suitable tie points (TPs) for some areas (e.g. in the shadow or in snow-covered areas). The different acquisition angles of the Ikonos data from different years represented an additional problem. This lead into an $\mathrm{rms}_{x, y}$ between the two Ikonos scenes of $7.8 \mathrm{~m}$. This error could be reduced by $100 \%$ (i.e. $4.0 \mathrm{~m}$ ) by the rectification of one scene to the other using rubber-sheeting (Peters, 2008).

\subsection{Methods}

\subsubsection{Glacial lakes}

Glacial lakes were automatically identified using the Normalised Differenced Water Index (NDWI, [NIRBLUE]/[NIR+BLUE]). Since ASTER lacks a BLUE channel the GREEN channel was used instead. Pixels misclassified due to shadows were eliminated based on a shadow calculation using the ASTER DEM. This method was successfully applied for the detection of water bodies (cf. Huggel et al., 2002). The NDWI performed slightly better than the band ratio ASTER1/ASTER3 (GREEN/NIR) which was used by Wessels et al. (2002) for uncalibrated data to detect glacial lakes in the Mt. Everest Region. In some scenes the glacial lakes were partly covered by ice (Table 1 ). Therefore, visual checking and editing was necessary. Manual delineation had to be applied for the topographic map and the Corona data. The contrast of the latter was stretched in order to improve the image quality. It was, however, still difficult to identify small, partly ice-covered lakes. Due to these problems and the coarse resolution of the Landsat MSS scene it was only possible to address the changes of the glacial lakes which are larger than $0.001 \mathrm{~km}^{2}$. However, a more detailed analysis was possible for the Khumbu Glacier for the year 2001 for which an Ikonos scene was available. The deviation between Ikonos and ASTER amounts to less than 10\%. The main reason for the deviation is that the small ponds are not detectable with the coarser resolution. The area of the Imja Lake classified in the year 2000 Landsat scene is $0.766 \mathrm{~km}^{2}$, while a manual delineation of Imja Lake (Bajracharya et al., 2007) based on the same Landsat scene resulted in $0.77 \mathrm{~km}^{2}$. Thus, the NDWI shows consistent results compared to manual delineations, but is much faster. 


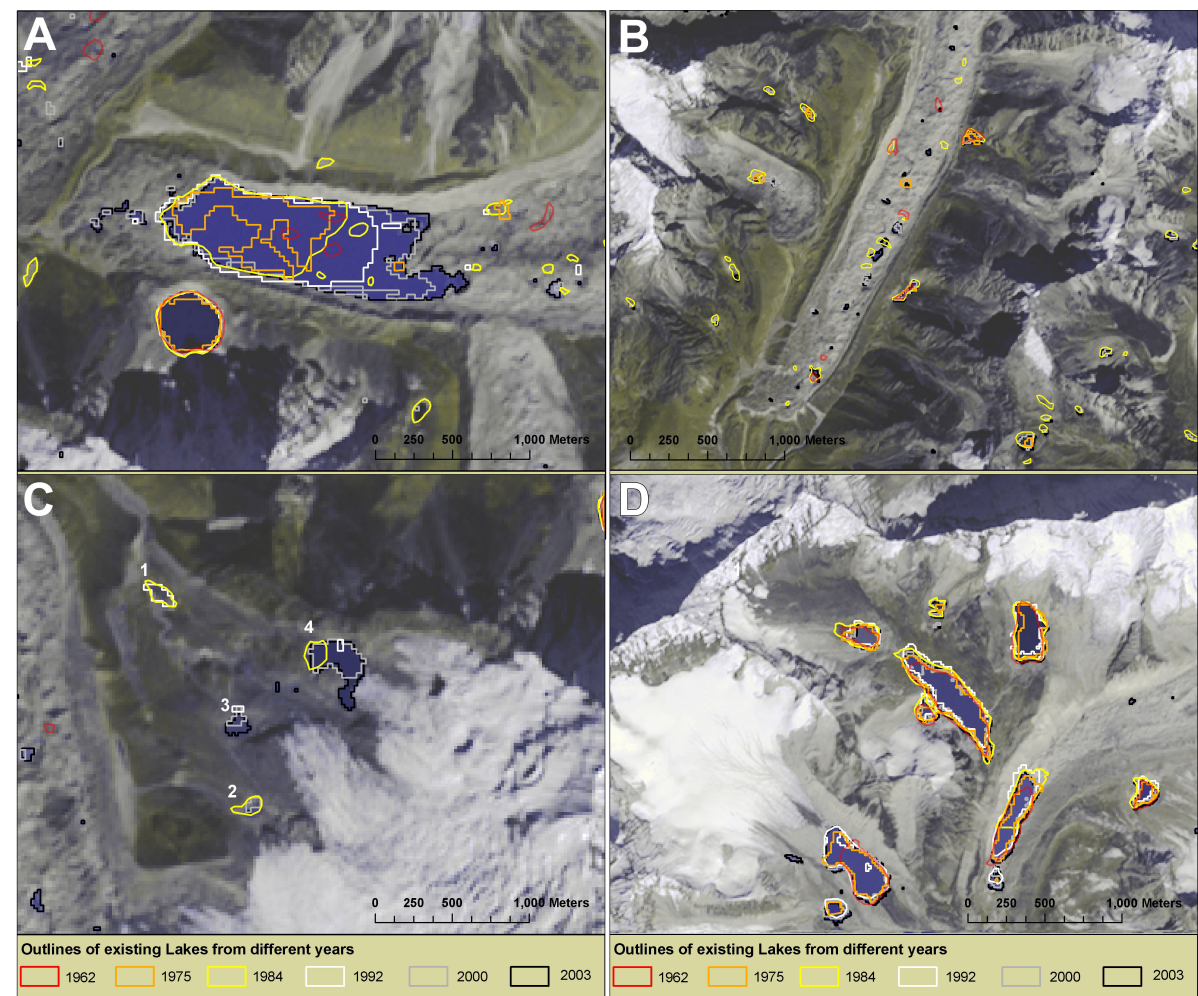

Fig. 2. Development of pre- and supraglacial lakes between 1962 and 2003 in different study sites. Background ASTER 3-3-1 from 2003. For locations see Fig. 1.

\subsubsection{Glacier flow velocity}

A common approach to derive the flow velocity of the glaciers is feature-tracking in imagery of different times. For glaciers, these individual features could be ice pinnacles, crevasses, boulders or a typical pattern of debris/ice which can be identified on both images. In this study, the displacement of the features was calculated using SSD3.0 (SAR Software Dresden, version 3.0). This software utilises imageto-image cross-correlation in conjunction with a subsequent least squares adjustment in order to precisely estimate subpixel accuracy. The feature-tracking technique identifies corresponding image blocks on both images. It was successfully applied to calculate velocity based on optical imagery both for large outlet glaciers (Lucchitta and Ferguson, 1986; Scambos et al., 1992) and mountain glaciers (Berthier et al., 2005; Kääb, 2005). The potential accuracy of the SSD3.0 software is in the order of $1 / 10$ of a pixel. However, due to the mentioned problems with the ortho-rectification, the overall accuracy is far less. In addition, different shadow casting which also occurs on the glacier surfaces due to the surface ponds and ice cliffs leads into matching and failure. These areas were masked and eliminated from the calculation.

Based on the GCPs the overall accuracy can be estimated to be $10.6 \mathrm{~m}$ for the ASTER scenes and $8.8 \mathrm{~m}$ for the Ikonos scenes. Despite the much higher resolution the overall accuracy of the Ikonos data is only slightly better than that of the ASTER scene. Ikonos can, however, corroborate the quality of the ASTER- based calculations.

\section{Results}

\subsection{Glacial lakes}

Due to determinations based on spaceborne imagery the overall area of the proglacial and supraglacial lakes in the study region increased from $2 \mathrm{~km}^{2}$ in 1962 to nearly $3.5 \mathrm{~km}^{2}$ in 2003. Most of the increase is due to the development of the Imja Lake which began to grow after 1962 and covered an area of more than $0.9 \mathrm{~km}^{2}$ in 2003 . Since its origin the area increase of the Imja Lake has been nearly linear. By contrast, the adjacent circular Amphulaptse Lake did not change its size during this period (Fig. 2A). The lakes south-west of Baruntse Peak and at the Hunku Glacier also did not change significantly since 1962 (Fig. 2D). The retreat of some debris-free glaciers caused the occurrence of proglacial lakes, e.g. north-east of Ama Dablam (Fig. 2C). Despite the downwasting of the Khumbu Glacier (Bolch et al., 2008), no large lake developed on this glacier, and constantly, no pond persisted on the glacier throughout the entire 

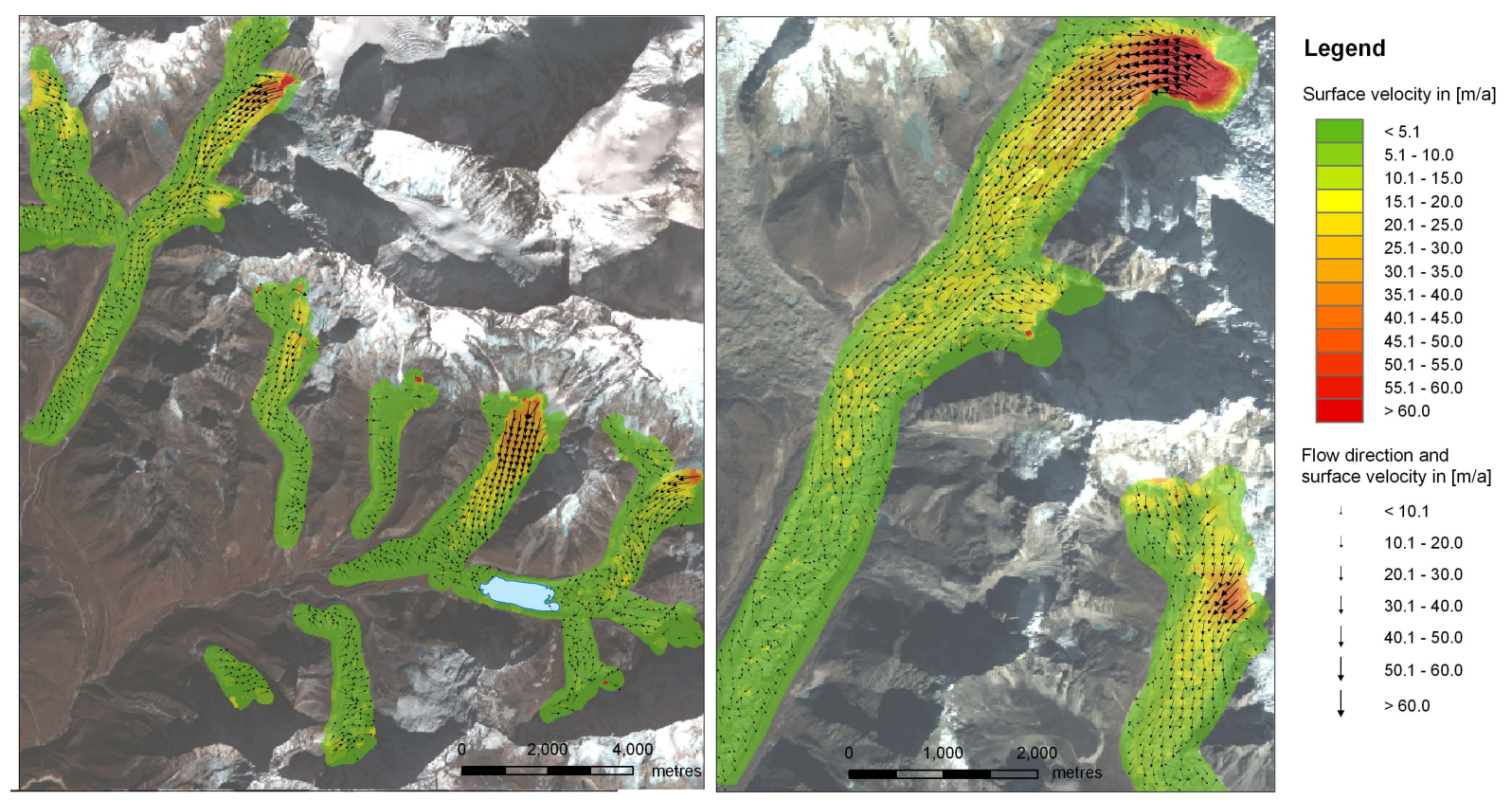

Fig. 3. Calculated surface velocities and flow directions based on ASTER data (left) and Ikonos data (right). The estimated location error amounts to $10.6 \mathrm{~m}$ for ASTER and $8.8 \mathrm{~m}$ for Ikonos data.

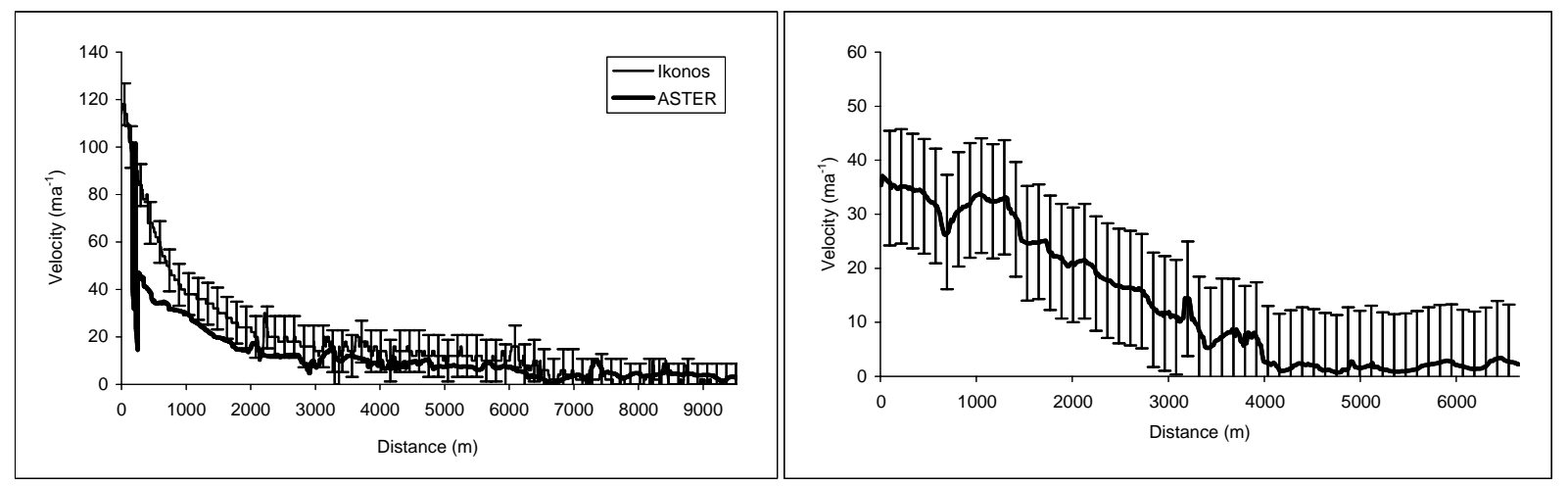

Fig. 4. Velocity profiles of Khumbu Glacier (left: Error bars for Ikonos data only) and Nuptse Glacier (right).

observation period. Nevertheless, between 1962 and 2000 the overall number and area of small ponds increased noticeably (Table 3). In 1984, however, the area covered by lakes was still much larger than in 2000. The main reason for this is that there was a comparatively large lake $\left(a=0.075 \mathrm{~km}^{2}\right)$ near the "Pinnacle Zone" which drained between 1984 and 2000. Also, a smaller lake $\left(a=0.016 \mathrm{~km}^{2}\right)$ near the eastern end of the terminus drained and is much smaller now.

The number of supraglacial lakes on the Lhotse Glacier increased but their area decreased slightly (Table 3).

In summary, there is an overall trend towards an increase of both the area and the number of glacial lakes. This trend, however, occurs only at some locations, whilst other locations do not seem to change much.

\subsection{Flow velocity}

The velocity field of the Khumbu Glacier based on the Ikonos data is, due to the high resolution, denser than that of the ASTER data, but the calculated velocities are corresponding (Figs. 3, 4). The values based on the Ikonos data are slightly higher but still in the same range, taking into account the location inaccuracy (Table 2). Overall, the velocity decreases from the upper part of the ablation zone to the terminus. The flow is clearly directional and varies from more than $50 \mathrm{ma}^{-1}$ to less than $30 \mathrm{ma}^{-1}$ in the upper debris-free zone. The calculated velocity at the snout and in the range of 2 to $4 \mathrm{~km}$ from the terminus (depending on the glacier) is less than the calculation inaccuracy, and the flow directions are inconsistent 
Table 3. Changes of number and area of glacial lakes at Khumbu and Lhotse Glacier 1962 to 2000. The numbers in brackets exclude the large lake at the "Pinnacle Zone" of Khumbu Glacier which existed in 1984.

\begin{tabular}{lcccccc}
\hline Glacier & \multicolumn{2}{c}{ Year 1962 } & \multicolumn{2}{c}{ Year 1984 } & \multicolumn{2}{c}{ Year 2000 } \\
& Nr. & Area $\left[\mathrm{km}^{2}\right]$ & Nr. & Area $\left[\mathrm{km}^{2}\right]$ & Nr. & Area $\left[\mathrm{km}^{2}\right]$ \\
\hline Khumbu & 8 & 0.04 & $16(15)$ & $0.13(0.06)$ & 19 & 0.08 \\
Lhotse & 9 & 0.04 & 18 & 0.05 & 19 & 0.03 \\
\hline
\end{tabular}

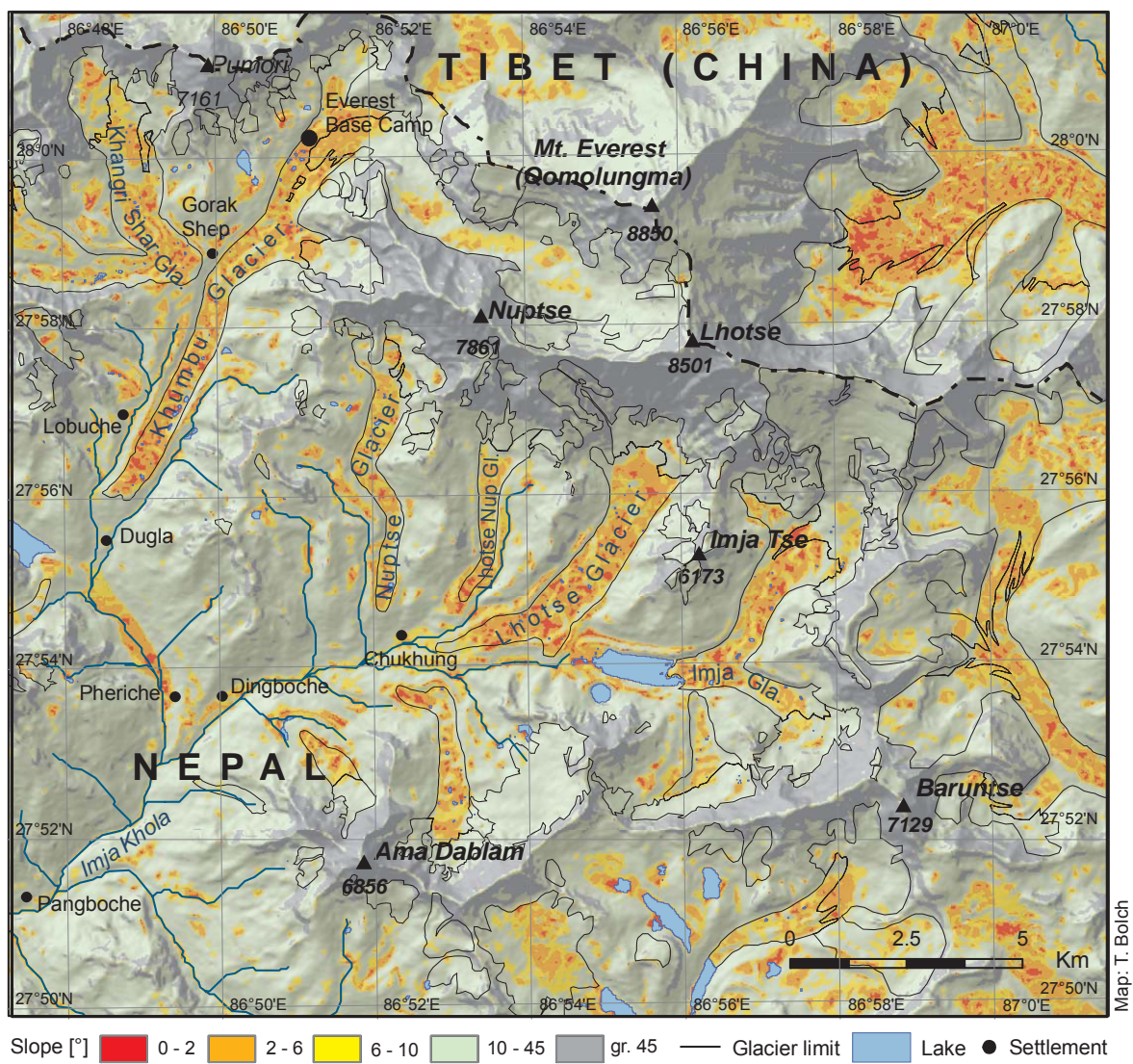

Fig. 5. Slope gradients of the whole study area.

there. Hence, these parts are moving slowly or are even stagnant. The end of the active glacier can be estimated for the Khumbu and Imja Glacier to be located about $3 \mathrm{~km}$, for the Nuptse and Lhotse Glacier approx. $2.5 \mathrm{~km}$ upstream the terminus (Figs. 3, 4). The tongue of the Lhotse Nup Glacier seems to be nearly stagnant, whilst the Lhotse Glacier is still very active in its middle course, up to about $3 \mathrm{~km}$ upstream the estimated terminus.

\subsection{Potentially dangerous glacial lakes (PDGLs)}

The analysis of the lake development shows that most of the lakes are ephemeral, they probably drain through englacial conduits and are therefore of low or no danger. In contrast, those lakes which can only drain via an incised spillway through the moraine, or when the moraine fails ("base-level lake" like the Imja Lake), are potentially dangerous. Important for the development of potentially dangerous glacial lakes is the down-wasting of the glacier tongues. Detailed studies based on the comparison of the 1962 Corona DTM and the 2002 ASTER DTM show a down-wasting at all parts of the investigated debris-covered tongues with the highest rates at the estimated transition zone between the active and the stagnant part. The Lhotse Glacier showed the lowest down-wasting rates (Bolch et al., 2008). These results are in line with a simulation for Khumbu Glacier which indicates the separation of the active part from the stagnant part about $3 \mathrm{~km}$ upstream the terminus (Naito et al., 2000). Thus one could expect the development of glacial lakes in this area. 


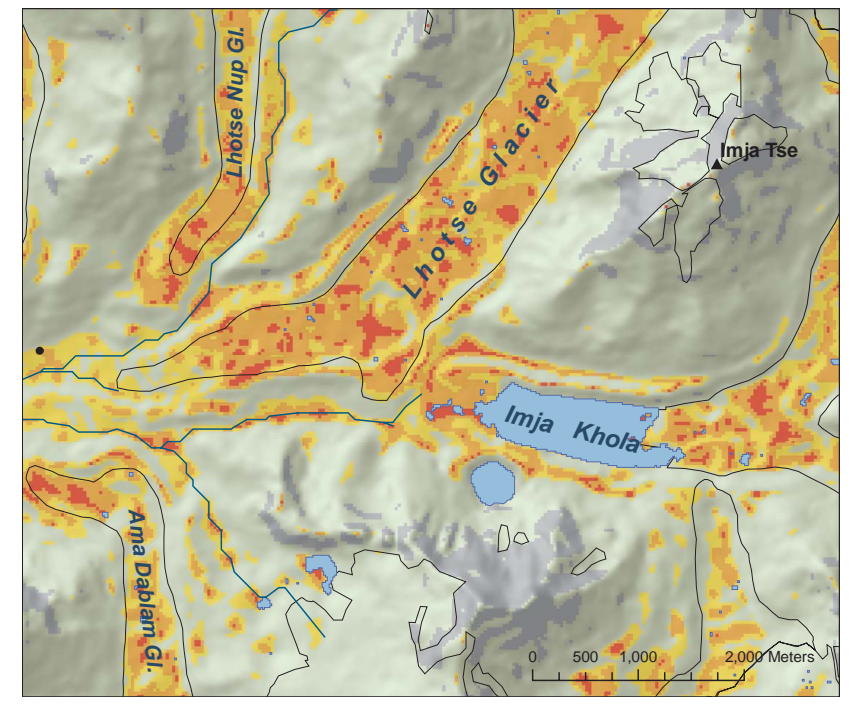

Fig. 6. Slope gradients of the termini of Lhotse Nup, Lhotse, Imja, and Ama Dablam Glacier; legend see Fig. 5.

A very important factor are the morphometric characteristics of the glaciers and their surroundings. The whole study area was divided into 5 slope classes using the ASTER DTM following the classification by Reynolds (2000) which has been verified for the study area by Quincey et al. (2007). As an additional class slopes steeper than 45 degree were separated which indicated probable source areas for mass movements and avalanches (Figs. 5, 6). Most of the debris-covered glacier tongues have a slope of less than $10^{\circ}$. This overall classification has, however, to be seen under the aspect that the tongues are characterised by ice cliffs and ponds, so that short steep slopes can also occur in the overall gentle terrain. Therefore, the average slope was smoothed to get a better idea of the overall characteristics. The calculated profiles based on this smoothed DTM also shed light on the possible sites of a lake development (Fig. 7). Furthermore, the slope conditions surrounding the existing glaciers are important to estimate the growth or the non-growth of a lake. The conditions of the whole catchment contain essential information for the risk of rock and ice (in combination with the ice cover) avalanches which may slide into a lake. For the latter, the shape of the catchment, represented by the profile curvature, is essential. A convex area above the lake might rather cause material to fall or slide into the lake. Characteristics of the moraines and the freeboard were manually addressed based on the ASTER DEM.

Based on the aforementioned facts the following conclusions regarding the development and the danger of existing or future lakes can be drawn (Table 4): Since its formation the growth rate of the Imja Lake is almost linear and it is very likely that the lake will continue growing. Analyzing the previous behaviour of the lake, the glacier velocities and

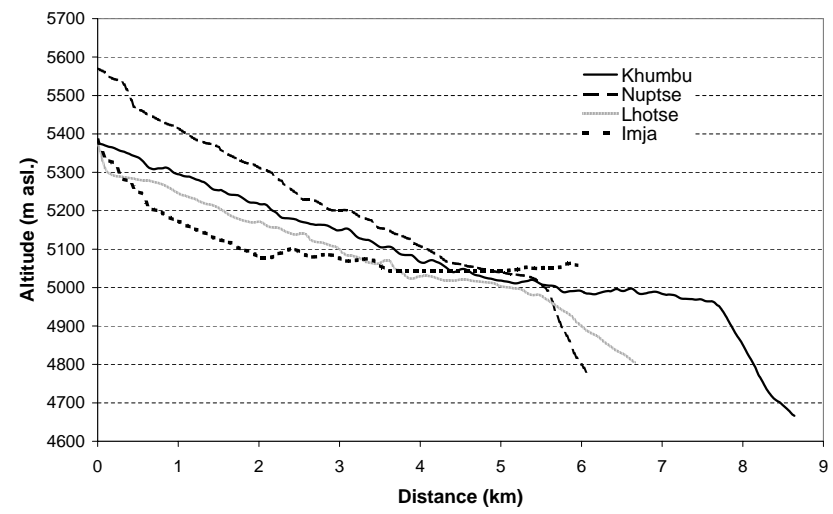

Fig. 7. Length profiles of selected glacier tongues.

the slope gradients of Imja, Lhotse Shar, and Amphu Glacier, in all likelihood the Imja Lake will continue growing "upstream" until the confluence of Imja Glacier and Lhotse Shar Glacier, whereupon the southern branch of the lake will probably grow faster. The latter fact might occur because the Amphu Glacier separated from the Imja Glacier and does no longer contribute ice. Despite lake growth the Glacial Lake Outburst Flood (GLOF) risk is not considered the highest, because the terminal moraine which dams the lake and where the spillway is incised is more than $500 \mathrm{~m}$ wide and the lake level is significantly lower than the lowest (southern) terrain and almost at the same level as the northern valley bottoms. This was also shown by Watanabe et al. (1994). The risk of a rockfall or an avalanche into the lake is low due to the surrounding relief. The terminal moraine contains, however, dead ice (Watanabe et al., 1995) and continuous warming will cause further melting. Due to the large volume of the lake, it should certainly be continuously monitored.

Less attention was paid to the other lakes in the area, their development and possible dangers. The proglacial lake in front of the rather clean Chukhung Glacier might have a higher risk of outburst flooding. The glacier receded faster than the debris-covered glaciers (Bolch et al., 2008) and the pro-glacial lake grew since the 1980s. There seems to be a significant risk of mass movements into this lake due to steep slopes. The lakes south-east of Baruntse Peak were relatively stable from 1962 to 2003 . Some of the lakes are cirque lakes and no longer in contact with a glacier. Also the area of the pro-glacial lake at the Hunku Glacier is relatively stable. Its glacier tongue is comparatively steep. Some lakes, however, show a slight GLOF risk due to steeper slopes in their surroundings. There is a chance of lake development on the Khumbu Glacier, due to the low flow velocity at its front, the continuing down-wasting and the gentle slope of the tongue. Due to its morphmetric and down-wasting characteristics (Bolch et al., 2008) it is likely that (additional) lakes will form at about $1 \mathrm{~km}$ from the stagnant terminus. However, the lake formation depends also on the englacial 
Table 4. Hazard risk of glacial lakes in the study area.

\begin{tabular}{|c|c|c|c|c|}
\hline Glacier/Location & Glacial Lake & Reason & PDGL & Reason \\
\hline $\begin{array}{l}\text { Imja Glacier } \\
\text { (Fig. 2a) }\end{array}$ & $\begin{array}{l}\text { Risk of growth up to } 1 \mathrm{~km} \\
\text { upglacier }\end{array}$ & $\begin{array}{l}\text { Glacier down-wasting, } \\
\text { Stagnant ice, slope sm. } 2^{\circ}\end{array}$ & Medium & $\begin{array}{l}\text { Only one small area where a } \\
\text { rock avalanche can reach the } \\
\text { lake, wide end moraine. }\end{array}$ \\
\hline $\begin{array}{l}\text { Khumbu Glacier } \\
\text { (Fig. 2b) }\end{array}$ & $\begin{array}{l}\text { risk about } 1 \mathrm{~km} \text { and } 3 \mathrm{~km} \\
\text { upstream the terminus }\end{array}$ & $\begin{array}{l}\text { Glacier down-wasting, } \\
\text { Stagnant ice, slope sm. } 2^{\circ}\end{array}$ & Low & $\begin{array}{l}\text { No steep slopes around, wide } \\
\text { end moraine }\end{array}$ \\
\hline Lhotse Glacier & No larger lake & $\begin{array}{l}\text { Velocity and slope condi- } \\
\text { tions }\end{array}$ & None & \\
\hline $\begin{array}{l}\text { Nuptse, Lhotse } \\
\text { Nup Glacier }\end{array}$ & $\begin{array}{l}500 \mathrm{~m} \text { to } 1 \mathrm{~km} \text { from the ter- } \\
\text { minus }\end{array}$ & $\begin{array}{l}\text { Glacier down-wasting, } \\
\text { Stagnant ice, slope sm. } 2^{\circ}\end{array}$ & Low & No steep slopes around \\
\hline $\begin{array}{l}\text { Chukhung Glacier } \\
\text { (Fig. 2c) }\end{array}$ & $\begin{array}{l}\text { Risk of growth and devel- } \\
\text { opment of some small lakes }\end{array}$ & Glacier recession & Medium & $\begin{array}{l}\text { Steep slopes, partly covered by } \\
\text { ice }\end{array}$ \\
\hline $\begin{array}{l}\text { Lakes SW of } \\
\text { Baruntse, Hunku } \\
\text { Glacier } \\
\text { (Fig. 2d) }\end{array}$ & $\begin{array}{l}\text { Some cirque lakes and two } \\
\text { pro-glacier lake }\end{array}$ & - & $\begin{array}{l}\text { Low to } \\
\text { Medium }\end{array}$ & $\begin{array}{l}\text { Lakes are nearly stable At least } \\
\text { since 1962, slight risk of rock or } \\
\text { ice avalanche into some lakes. }\end{array}$ \\
\hline
\end{tabular}

drainage which cannot be investigated through remote sensing. At the Lhotse Glacier a larger lake will most likely not occur, due to the higher flow velocity in the part with lower slopes. Here the slope exceeds $6 \%$ at the parts with low or no glacier flow.

\section{Discussion}

\subsection{Glacial flow velocity}

As shown, the results of the velocity calculation based on ASTER data are in the same range of those based on the Ikonos data. Hence, calculations based on ASTER data can be considered reliable despite the much lower resolution than that of the Ikonos data. This corroborates the findings of Kääb (2005) that velocity calculations based on ASTER data using feature matching are also suitable for mountain glaciers and debris-covered glaciers.

So far, only few studies exist which investigated the velocity of the Khumbu Glacier during the second half of the 20th century. Müller (1968) measured the velocitiy of the glacier surface from April until November 1956 at the Everest Base Camp (EBC) and at the end of the "Pinnacle Zone" (at the transition between clean ice and debris-covered ice) and found velocities of $58 \mathrm{ma}^{-1}$ and $28 \mathrm{ma}^{-1}$ respectively. Seko et al. (1998) used topographic maps and SPOT satellite imagery to estimate surface displacements at the same sites for multiple time periods between 1956 and 1995. At the EBC they found velocities in the same range, which decreased from about $70 \mathrm{ma}^{-1}$ to about $50 \mathrm{ma}^{-1}$. The displacements for the "Pinnacle Zone" decreased from $56 \mathrm{ma}^{-1}$ to $26 \mathrm{ma}^{-1}$. In the early 1970s Kodama and Mae (1976) measured by triangulation velocities of about $20 \mathrm{ma}^{-1}$ south of the former confluence of the Changri Shar Glacier with the Khumbu Glacier ( $5 \mathrm{~km}$ downstream EBC) and only $1 \mathrm{ma}^{-1}$ near the terminus south-east of Lobuche $(8.55 \mathrm{~km}$ downstream EBC). Nakawo et al. (1999) measured, based on two SPOT scenes from 1987 and 1993, 10-20 ma-1 $5 \mathrm{~km}$ downstream EBC and 5-10 $\mathrm{ma}^{-1} 7 \mathrm{~km}$ downstream EBC. A recent study based on ERS data from the mid 1990s resulted in velocities of about $50 \mathrm{ma}^{-1}$ at the EBC and less than $20 \mathrm{ma}^{-1}$ south of the "Pinnacle Zone" with an almost stagnat part at the front of the terminus (Luckman et al., 2007). Velocity measurements for the Lhotse Glacier, also based on ERS data, showed that the debris-covered glacier tongue is stagnant up to $2 \mathrm{~km}$ upstream the terminus (Quincey et al., 2007).

Our own results are in line with the previously published data and confirm the trend of decreasing velocities and the likelihood of existing stagnant ice at the terminus of each debris-covered glacier tongue. However, the stagnant parts could not be clearly delineated due to the estimated error of about $\pm 10 \mathrm{~m} / \mathrm{a}$. Stagnant ice was estimated to reach about $3 \mathrm{~km}$ upstream from the terminus of the Khumbu Glacier in the 1970s and probably a little higher in the 1990s (Fushimi, 1977; Luckman et al., 2007). The fact that the supraglacial ponds are ephemeral and no larger lake developed in this part so far - although the down-wasting is highest about 2 to $4 \mathrm{~km}$ upstream the terminus (Bolch et al., 2008) - indicates that an englacial or subglacial drainage system is existing. Slight ice movements at this part may support the inflow into this drainage system. Surface features also shed light on the glacier activity. The larger portion of the estimated stagnant part has a rougher surface characterised by ice cliffs, whereas the frontal part up to about $1 \mathrm{~km}$ upstream is smooth with only gentle slopes at the surface. Hence, this area is stagnant, whereas the area beween about 1 to more than $3 \mathrm{~km}$ upstream is "almost stagnant". The Nuptse Shar 
and Imja Glacier show charcteristics similar to the Khumbu Glacier, apart from the fact that at the latter ones the stagnant ice areas are larger and the active ice areas are detached from the stagnant part so that a lake could develop. Surface characteristics and the velocity measurements indicate stagnant ice $2 \mathrm{~km}$ upstream the Lhotse Glacier terminus. In contrast to the other glaciers this stagnant part is comparatively steep.

\subsection{Potentially dangerous glacial lakes}

The aforementioned results show that the identification of glacial lakes using the NDWI leads to accurate results. This also confirms earlier studies (e.g. Huggel et al., 2002). Lake identification based on ASTER is slightly more accurate than of Landsat as the comparison with the Ikonos data demonstrates. The automated lake identification can be problematic with turbid lakes and lakes with partial ice cover/icebergs, and in shadow areas. In these cases an improvement based on visual interpretation or a complex classification method like artificial neural networks (ANN) is needed.

Not only the numbers of the lakes delineated by our automated approach (concerning the years 1975, 2000, 2003), but also the numbers of the manually delineated/improved water bodies are in agreement with previous studies (e.g. Bajracharya et al., 2007; Gspurning et al., 2004; Watanabe et al., 1994, 1995; Yamada, 1998).

Data from the earlier years, however, represent problems: The Corona data is only panchromatic, and radiometric image enhancement procedures are required. Grey values of turbid lakes can be similar to those of other features and hence an identification of these lakes can be challenging. The use of topographic maps can be also problematic, since their quality depends on the purpose of the map, the utilized data and the skills of the cartographer. The National Geographic map, which was used for this study, is based on high resolution aerial photographs and much attention was drawn to an accurate mapping of the glaciers and its characteristics. Clearly, the medium resolution of Landsat MSS (80 m) hampers the identification of smaller lakes. Nevertheless, these data are of tremendous use in order to study the lake development since 1962.

The utilized ASTER DEM represents the surface characteristics quite well (Buchroithner and Bolch, 2007) and is therefore suitable to assess the morphometric characteristics of the surroundings of the glacial lakes. The suitability of ASTER DEMs for assessing glacial lakes in the Bhutanese Himalaya is also shown in a recent study (Fujita et al., 2008). The slope thresholds of $2^{\circ}$ (formation of supraglacial ponds over stagnant or very slow moving ice is likely) and $6^{\circ}$ (supraglacial ponds form, but may also be transient locally) which were suggested in previous studies (Quincey et al., 2007; Reynolds, 2000) are suitable to estimate the potential area where a lake could form and/or grow. However, at the hummocky surface of the debris-covered glaciers the slope varies within a short distance. A smoothed DEM is recom- mended to obtain the overall surface gradient. Nevertheless, those suggested thresholds are guidance levels. A value of smaller than $5^{\circ}$ was suggested as the critical slope value for the Alps (Frey et al., 2008). The ASTER DEM is also useful to obtain information about the freeboard and the moraines.

Many important parameters to assess the GLOF risk can be obtained using remote sensing data. However, some cannot be extracted (e.g. lake depth), need manual interpretation (e.g. the freeboard or the characteristics of the moraines based on DEM analysis or the existence of englacial or subglacial drainage systems through multi-temporal image analysis of lake existences). The presented table with the estimated GLOF risk represents therefore an estimate based on the available data and parameters and further investigations are recommended. In order to asses the potential danger of an outburst flood to human life and infrastructure, the possible affected area has to be taken into account (e.g. an outburst of Imja Lake would affect several downstream villages; Bajracharya et al., 2007).

\section{Conclusions}

Remote sensing is a good tool for displacement calculations and risk assessment regarding PDGLs. It is especially helpful for remote mountainous areas. ASTER data has suitable accuracy to calculate the surface velocity. Ikonos data offers more detail but requires also more effort for rectification. All investigated debris-covered glacier tongues show areas with no or very slow movement rates. The lakes and their change since 1962 could be illustrated and their possible dangers quantified. The approach based on lake change, glacier flow velocity, surface slope, and moraine characteristics is suitable to identify possible future lake sites and to estimate the possible danger of an outburst. However, not all important parameters can be obtained using space imagery alone, some require additional interpretation by an expert. This is especially true for the existence of a drainage system, depth measurements of the lakes in order to obtain lake volume, and measurements of the ice/permafrost content of the terminal and lateral moraines. A lot of progress in the utilization of remote sensing data has been made since the first studies (e.g. Buchroithner et al., 1982): Higher resolution imagery and DEMs, the inclusion of the geology (lithology, tectonics/seismic events), climatic conditions, and permafrost modelling are able to improve the risk assessment in the near future. However, when human lives and infrastructure are endangered, additional field investigations are still recommended.

Acknowledgements. This publication presents results of the project "Monitoring of Glaciers and Glacial Lakes at Mt. Everest" which was funded by the German Research Foundation (DFG) under the code BU 949/15-1. The authors like to thank Ulrich Kamp (University of Montana, USA) for the initiation of this project. The cooperation with Basanta Shrestha and Arun B. Shrestha 
(ICIMOD, Nepal) is very much appreciated. ASTER data were provided at no cost through NASA/USGS under the umbrella of the GLIMS project. Furthermore, we are grateful for the valuable comments of D. Benn and J. Calvet.

Edited by: J. M. Vilaplana

Reviewed by: D. Benn and J. Calvet

\section{References}

Bajracharya, S. R., Mool, P. K., and Shrestha, B. R.: Impact of climate change on Himalayan glaciers and glacial lakes, ICIMOD, Kathmandu, pp. 119, 2007.

Benn, D., Wiseman, S., and Warren, C.: Rapid growth of a supraglacial lake, Ngozumpa Glacier, Khumbu Himal, Nepal, IAHS Publ. 264 (=Debris-Covered Glaciers), 177-186, 2000.

Benn, D. I., Wiseman, S., and Hands, K. A.: Growth and drainage of supraglacial lakes on debris mantled Ngozumpa Glacier, Khumbu Himal, Nepal, J. Glaciol., 47(159), 626-638, 2001.

Berthier, E., Vadon, H., Baratoux, D., Arnaud, Y., Vincent, C., Feigl, K. L., Rémy, F., and Legrésy, B.: Surface motion of mountain glaciers derived from satellite optical imagery, Remote Sens. Environ., 95(1), 14-28, 2007.

Bolch, T., Buchroithner, M. F., Kunert, A., and Kamp, U.: Automated Delineation of debris-covered glaciers based on ASTER data, in: GeoInformation in Europe (=Proc. 27th EARSeLSymposium, 4.-7.6.07, Bozen, Italy), edited by: Gomarasca, M. A., Millpress, Netherlands, 403-410, 2007.

Bolch, T., Buchroithner, M. F., Pieczonka, T., and Kunert, A.: Planimetric and volumetric Glacier changes in Khumbu Himalaya since 1962 using Corona, Landsat TM and ASTER data, J. Glaciol., 54(187), 592-600, 2008.

Buchroithner, M. F.: Problems of mountain hazard mapping using spaceborne remote sensing techniques, Adv. Space Res., 15(11), 57-66, 1995.

Buchroithner, M. F.: Jökulhlaup mapping in the Himalaya by means of remote sensing, Kartographische Bausteine 12 (=Proc. Int. Symp. of High Mountain Remote Sensing Cartography, Schladming, Austria 1990), 75-86, 1996.

Buchroithner, M. F. and Bolch, T.: An Automated Method to Delineate the Ice Extension of the Debris-Covered Glaciers at Mt. Everest Based on ASTER Imagery, Grazer Schriften der Geographie und Raumforschung 43 (=Proc. of the 9th int. symp. on high mountain remote sensing cartography, 14-22 Sep. 2006, Graz, Austria), 71-78, 2007.

Buchroithner, M., Jentsch, G., and Wanivenhaus, B.: Monitoring of recent geological events in the Khumbu area (Himalaya, Nepal) by digital prosessing of Landsat MSS Data, Rock Mechanics 15, 181-197, 1982

Frey, H., Haeberli, W., Paul, F., Linsbauer, A., Zemp, M., and Huggel, C.: Modelling the formation of future glacial lakes by means of GIS-based methods, Geophys. Res. A., 10, EGU2008A-03165, 2008

Fujita, K., Suzuki, R., Nuimura, T., and Sakai, A.: Performance of ASTER and SRTM DEMs, and their potential for assessing glacial lakes in the Lunana region, Bhutan Himalaya, J. Glaciol., 54(185), 220-228, 2008.

Fushimi, H.: Sructural Studies of Glaciers in the Khumbu Region, J. Jap. Soc. Snow and Ice 39, Special Issue, 30-39, 1977.
Gspurning, J., Kostka, R., and Sulzer, W.: Applicability of available Geodata in high mountain environmental research - examples from the Khumbu Himal Area (NEPAL), in: Proceedings of the 19th European \& Skandinavian Conference for ESRI Users, Copenhagen. pp. 13, 2004.

Gulley, J. and Benn, D. I.: Structural control of englacial drainage systems in Himalayan debris-covered glaciers, J. Glaciol., 53(182), 399-412, 2007.

Huggel, C., Kääb, A., Haeberli, W., Teysseire, P., and Paul, F.: Remote sensing based assessment of hazards from glacier lake outbursts: a case study in the Swiss Alps, Can. Geotech. J., 39, 316-330, 2002.

Huggel, C., Zgraggen-Oswald, S., Haeberli, W., Kääb, A., Polkvoj, A., Galushkin, I., and Evans, S. G.: The 2002 rock/ice avalanche at Kolka/Karmadon, Russian Caucasus: assessment of extraordinary avalanche formation and mobility, and application of QuickBird satellite imagery, Nat. Hazards Earth Syst. Sci., 5, 173-187, 2005 , http://www.nat-hazards-earth-syst-sci.net/5/173/2005/.

Ives, J.: Glacial lake outburst floods and risk engineering in the Himalaya, ICIMOD, Occasional Paper 5, Kathmandu, pp. 42, 1986.

Kääb, A.: Combination of SRTM3 and repeat ASTER data for deriving alpine glacier flow velocities in the Bhutan Himalaya, Rem. Sens. Environ. 94(4), 463-474, 2005.

Kääb, A., Huggel, C., Fischer, L., Guex, S., Paul, F., Roer, I., Salzmann, N., Schlaefli, S., Schmutz, K., Schneider, D., Strozzi, T., and Weidmann, Y.: Remote sensing of glacier- and permafrostrelated hazards in high mountains: an overview, Nat. Hazards Earth Syst. Sci., 5, 527-554, 2005, http://www.nat-hazards-earth-syst-sci.net/5/527/2005/.

Kattelmann, R.: Glacial lake outburst floods in the Nepal Himalaya: A manageable hazard?, Nat. Hazards, 28(1), 145-154, 2003.

Kodama, H. and Mae, S.: Flow of glaciers in the Khumbu region, J. Jap. Soc. Snow and Ice Special Issue 38(Part I), 31-36, 1976.

Kadota, T., Seko, K., Aoki, T., Iwata, S., and Yamaguchi, S.: Shrinkage of Khumbu Glacier, east Nepal from 1978 to 1995 , IAHS Publ. 264 (=Debris-Covered Glaciers), 235-243, 2000.

Luckman, A., Quincey, D., and Bevan, S.: The potential of satellite radar interferometry and feature tracking for monitoring flow rates of Himalayan glaciers, Rem. Sens. Environ., 111(2-3), 172-181, 2007.

Lucchitta, B. K. and Ferguson, H. M.: Antarctica: measuring glacier velocity from satellite images, Science, 234(4780), 11051108, 1986.

Mool, P. K., Bajracharrya, S. R., and Joshi, S. P.: Inventory of Glaciers, Glacial Lakes, Glacial Lake Outburst Floods: Monitoring and Early Warning Systems in the Hindu Kush-Himalayan Region, Nepal, ICIMOD, Kathmandu, pp. 386, 2007.

Müller, F.: Mittelfristige Schwankungen der Oberflaechengeschwindigkeiten des Khumbugletschers am Mount Everest, Schweizerische Bauzeitung, 86(31), 569-573, 1968.

Naito, N., Nakawo, M., Kadota, T., and Raymond, C. F.: Numerical simulation of recent shrinkage of Khumbu Glacier, Nepal Himalayas, IAHS Publ. 264(=Debris-Covered Glaciers), 245-254, 2000.

Nakawo, M., Yabuki, H., and Sakai, A.: Characteristics of Khumbu Glacier, Nepal Himalaya: recent changes in the debris-covered area, Ann. Glaciol. 28, 118-122, 1999. 
National Geographic Society (NGS): Mount Everest - Sargarmatha (Nepali) - Qomolangma (Chinese), (Scale 1:50000), Washington, DC, National Geographic Society, 1988.

Peters, J.: Erfassung und Visualisierung der Bewegungsraten der Gletscher am Mount Everest anhand multitemporaler Satellitendaten, Semester Thesis, Institute for Cartography, Technische Universität Dresden, Germany, 62 pp., 2008.

Quincey, D. J., Lucas, R. M., Richardson, S. D., Glasser, N. F., Hambrey, M. J., and Reynolds, J. M.: Optical remote sensing techniques in high-mountain environments: application to glacial hazards, Prog. Phys. Geog. 29(4), 475-505, 2005.

Quincey, D. J., Richardson, S. D., Luckman, A., Lucas, R. M., Reynolds, J. M., Hambrey, M. J., and Glasser, N. J.: Early recognition of glacial lake hazards in the Himalaya using remote sensing datasets, Global Planet. Change, 56(1-2), 137-152, 2007.

Reynolds, J. M.: On the formation of supraglacial lakes on debriscovered glaciers, IAHS Publ. 264 (=Debris-covered Glaciers), 153-161, 2000.

Richardson, S. D. and Reynolds, J. M.: An overview of glacial hazards in the Himalayas, Quatern. Int., 65/66(1), 31-47, 2000.

Sakai, A., Saito, M., Nishimura, K., Yamada, T., Izuka, Y., Harado, K., Kobayashi, S., Fujita, K., and Gurung, C. B.: Topographical survey of end moraine and dead ice area at Imja Glacial Lake in 2001 and 2002, Bulletin of Glaciological Research 24, 29-36, 2007.

Scambos, T. A., Dutkiewicz, M. J., Wilson, J. C., and Bindschadler, R. A.: Application of image cross-correlation to the measurement of glacier velocity using satellite image data, Rem. Sens. Environ., 42(3), 177-186, 1992.

Scherler, D., Leprince, S., and Strecker, M. R.: Glacier-surface velocities in alpine terrain from optical satellite imagery - Accuracy improvement and quality assessment, Rem. Sens. Environ., 112(10), 3806-3819, 2008.
Seko, K., Yabuki, H., Nakawo, M., Sakai, A., Kadota, T., and Yamada, Y.: Changing surface features of Khumbu Glacier, Nepal Himalayas, revealed by SPOT images, Bulletin of Glacier Research, 16, 33-41, 1998.

Ueno, K., Kayastha, R. B., Chitrakar, M. R., Bajracharrya, S. R., Pokhrel, A. P. Fujinami, H., Kadota, T., Iida, H., Manandhar, D. P., Hattori, M., Yasunari, T., and Nakawo, M.: Meteorological observations during 1994-2000 at the Automatic Weather Station (GEN-AWS) in Khumbu region, Nepal Himalayas, Bulletin of Glaciological Research, 18, 23-30, 2001.

Vuichard, D. and Zimmermann, M.: The 1985 catastrophic drainage of a moraine-dammed lake, Khumbu Himal, Nepal: cause and consequences, Mt. Res. Dev., 7, 91-110, 1987

Watanabe, T., Ives, J., and Hammond, J.: Rapid Growth of a Glacial Lake in Khumbu Himal, Nepal: Prospects for a Catastrophic Flood, Mt. Res. Dev., 14(4), 329-340, 1994.

Watanabe, T., Kameyama, S., and Sato, T.: Imja glacier deadice melt rates and changes in a supraglacial lake, 1989-1994, Khumbu Himal, Nepal: danger of lake drainage, Mt. Res. Dev., 15, 293-300, 1995.

Watanabe, T. and Rothacher, D.: The 1994 Lugge Tsho Glacial Lake Outburst Flood, Bhutan Himalaya, Mt. Res. Dev., 16(1), 77-81, 1996

Wessels, R. L., Kargel, J. S., and Kieffer, H. H.: ASTER measurement of supraglacial lakes in the Mount Everest region of the Himalaya, Ann. Glaciol. 34, 399-408, 2002.

Yamada, T. and Sharma, C. K.: Glacier lakes and outburst floods in the Nepal Himalaya, IAHS Publ. 218 (=Snow and glacier hydrology), 319-330, 1993.

Yamada, T.: Glacier lake and its outburst flood in the Nepal Himalaya. Monograph 1, Data Center for Glacier Research, Japanese Society for Snow and Ice, Tokyo, 99 pp., 1998. 